\title{
Sarız (Kayseri) Yöresi Düz Dokumaları ve Günümüzdeki
}

\section{Durumu}

Zahide KAYIŞOĞLU ŞAHIN*

\section{ÖZET}

Sarız ilçesinin eski adı köyyeri iken daha sonra Sarız şeklinde değiştirilmiştir. Sarız adının nerden geldiği konusunda yöre halkı: Sarı kız'dan geldiği, Sarız'ın içinden geçen ırmaktan aldığı, yörede yetişen Sarı Çiçek'ten aldı ı̆ı şeklinde bilgiler vermiş̧ir. Dokumacılık sanatı, Sarız Merkez'de,Yeşilkent kasabasında ve bazı köylerde hâlâ yapılmaktadır. Sarız merkez ve köylerinde dokunan düz dokumaları üç sınıfa ayırabiliriz:

1-Geleneksel Sarız Dokumaları

2-Değişik illerden gelerek Sarız'a yerleşen kişilerin, geldikleri yerlerdeki dokuma bilgilerini Sarı' a getirerek, uzun yıllar Sarız'da dokudukları dokumalar. 3-Son yıllarda düz dokumalara artan talepten dolayı Ticari amaçla dokunan dokumalar. Dokumalarda kullanılan ipler önceki yıllarda elde eğirilip, doğal boyalarla boyanmaktayken günümüzde ipler neredeyse boyalı şekilde ve hazır alınmaktadır. Sarma tip tezgahlar, her geçen gün yerini germe tip tezgahlara bırakmaktadır. Fabrikasyon ürünlere kolaylıkla ulaşılabildiğinden, geleneksel el dokumalarına ihtiyaç azalmış ve dokumacılık neredeyse yapılmamaktadır. Halı esnafının istediği renklerde, desenlerde dokumalar ücret karşılığı dokunmaktadır.

Anahtar Kelimeler: Sarız, Kilim, Büküm Aletleri, Doğal Boyamacılık, Seleser.

* Öğretim Görevlisi, Erciyes Üniversitesi Mustafa Çıkrıç̧ıŏlu M.Y.O. Geleneksel El Sanatları Bölümü, Melikgazi / KAYSERI zahide@erciyes.edu.tr

** Bu araştırmamda emeğini esirgemeyen başta eşim Sayın Cihat Şahin'e, canım kızım Derin Şahin'e, kardeşim Ayşe Kayışoğlu'na. öğrencilerime, tüm yöre halkına sonsuz teşekkürlerimle.

\section{ABSTRACT}

While the former name of the town Köyyeri Sarız later changed to Sarız. Where the name of the local people in that Sarı: Yellow girl came, the river that runs through Sarı in the region has grown Yellow flower the information in the form.

The art of weaving, Sarız the Center, Yeşilkent are still in town and in some villages.

Plain woven fabrics can be divided into three classes Sarız centers and villages:

1-Traditional Sarız fabrics

Settled in different cities came Sarız 2-persons, where they came Sarız woven details, bringing the fabrics woven by Sarız for many years.

3-in recent years due to increasing demand flat textiles woven fabrics for commercial purposes.

Used in weaving yarns made from previous years, and ready to be painted in natural dyes boyanmaktayken today is almost the ropes. Winding-type counter tops, countertops leaves replaced every other day type of stretching. Fabricated products easily reachable, and reduced need for traditional hand weaving dokumalarına almost done here. Carpet trades at any colors, patterns, fabrics woven for a fee.

Key Words: Sarız, Rug, Bending Tools, Natural Dyeing, Seleser.

\section{Giris}

Kilimleri ile ün salan, 1946 yllında ilçe konumuna gelen Sarız, Kayseri'nin 140 km. doğusundadır 
ve merkeze en uzak ilçedir ${ }^{1}$. İl merkezinin güneydoğusunda Tahtalı dağlarının eteklerinde Sarız suyu (Göksu) vadisinde kurulmuştur². Kayseri'ye bağlı ilçe, Anadolu'nun Doğu Anadolu ve Akdeniz Bölgelerinin birleştiği kesimdedir. Topraklarını, doğuda K.Maraş'ın Afşin, güneydoğuda Kayseri'nin Tomarza, kuzeybatıda ve kuzeyde aynı ilin Pınarbaşı, kuzeydoğuda Sivas'ın Gürün ilçeleri çevirir³ ${ }^{3}$ Sarız'ın yüzölçümü 1239 km² olup bu alanın büyük bir kısmını dağlar, yaylalar teşkil eder. Deniz seviyesinden 1560 m. dir ${ }^{4}$. Sarız, yazları sıcak ve kurak, kışları soğuk ve yağışlıdır. Rakımı 1500 metreyi bulduğu için, iklimi özellikle kışın oldukça serttir. Yazında diğer ilçelere oranla serin geçer ${ }^{5}$. İlçede ekonomik hayat özellikle hayvancılı̆̆a dayanır. Ayrıca tarım ve dokumacılık da başta gelen geçim kaynaklarındandır. Tahıl ürünlerinden buğday, arpa, çavdar ve yulaf yetiştirilir6́.

Sarız merkez ilçeye bağlı 37 köyden oluşmaktadır: Akoluk, Altısöğüt, Ayranlık, Büyükörtülü, Büyüksöbeçimen, Çağşak, Çavdar, Çörekdere, Dallıkavak, Darıdere, Dayoluk, Değirmentaş, Fettahdere, Gümüşali, İncedere, İncemağara, Kemer, Karakoyunlu, Karapınar, Karayurt, Kırkısrak, Kıskaçlı, Kurudere, Kuşçu, Küçükkabaktepe, Küçükörtülü, Küçüksöbeçimen, Mirzaağa, Mollahüseyinler, Oğlakkaya, Ördekli, Sancakkağıl, Tavlaköy, Tekneli, Yaylacı, Yedioluk . Yeşilkent ise ilçenin tek kasabasıdır.

Sarız merkezinin adının eskiden köyyeri iken daha sonra Sarız şeklinde değiştirilmiştir. Sarız adının nerden geldiği konusunda yöre halkı:

Sarı kız'dan geldiği,

Sarız'ın içinde aktığı ırmaktan yer aldı̆̆ı;

Yörede yetişen Sarı Çiçek'ten aldığı şeklinde üç farklı şekilde açılama getirmiştir.

İlçe ve çevresi bir süre Klikya, ermeni krall-ğ1 ve Bizans yönetiminde kalmış daha sonraları Dulkadiroğulları'nın hakimiyetine girmiştir. Yavuz

1 Kayseri'de El Sanatlarl; Türkiye Cumhuriyeti Kayseri Turizm, Kültür, Sanat ve Araştırma Vakfı Yayınları no: 3.

2 Gülderen Kılıç; Sarız ve Çevresinde Yaşayan Avşarların Örf ve Adetlerinin Tetkiki, Yayınlanmamış Lisans tezi (E.Ü. İlahiyat Fak.), Kayseri 1996, s.8

3 Mehmet Arık; Sarız Tarihi, Yayınlanmamış Lisans Tezi (E.Ü. İlahiyat Fak.), Kayseri 1983, s.7

4 Gülderen Kılıç; Sarız ve Çevresinde Yaşayan Avşarların Örf ve Adetlerinin Tetkiki, Yayınlanmamış Lisans Tezi (E.Ü. İlahiyat Fak.), Kayseri 1996, S.8

5 Muhsin İlyas Subaşı; Dünden Bugüne Kayseri, Geçit Yayınevi, Kayseri 1998, 4. baski, s.280

6 Mehmet Arık; Sarız Tarihi, Yayınlanmamış Lisans Tezi (E.Ü. İlahiyat Fak.), Kayseri 1983, s.13.

7 Muhsin İlyas Subaşı; Dünden Bugüne Kayseri, Geçit Yayınevi, Kayseri 1998, 4. bask1, s.281.

8 Muhsin İlyas Subaşı, Dünden Bugüne Kayseri, Geçit Yayınevi; 4. Bask1, Kayseri, 1998, s.281
Sultan döneminde ise Osmanlı Devletinin hakimiyetine girmiştir.

Osmanlı Devletinin yönetiminde bulunan ve Adana yöresinde yaşayan Avşarlar Sarız'ı uzun yıllar yayla olarak kullanmışlar ve 1840 yıllarında ilçeye yerleşmişlerdir. İlçe herhangi bir düşman işgaline uğramamıştır.

Bugün Kayseri'nin Pınarbaşı, Sarız, Tomarza gibi ilçelerinin köylerinde yaşayan Avşarlar Koca-Nallı obasına bağlı Avşarlardır. Sadece Sarız ilçesine bağlı İncidere ve Esirlik adlı köylerde bulunan Avşarlar Türkmen Aliler obasındandır?

Sarı' da Avşarlarla birlikte Kürtler ve Çerkezlerde vardır. Sarız'ın Avşarları yarı göçebe halinde yazlarını Uzunyayla'da, kışlarını Adana'nın Kadirli kazası ile Ceyhan ilçesi arasında geçirmekte iken, 1856 yıllarında Türkiye'ye göç eden Çerkezler Uzunyayla'ya yerleşmişler ${ }^{10}$.

Dokumacılık, Sarız Merkez'de, Yeşilkent kasabasında ve bazı köylerde hâlâ yapılmaktadır. Dokumacılığın yapıldığı köyler: Akoluk, Ayranlık, Büyükörtülü, Büyüksöbeçimen, Çağşak, Çavdar, Çörekdere, Dayoluk, Damızlık, Gerdekmağara, Kemer, Karapınar, Kırkısrak, Kurudere, Küçükörtülü, Küçüksöbeçimen, Tavla, Tekneli, Yaylacı'dır.

\section{Sarız Yöresi Dokumaları}

Sarız merkez ve köylerinde dokunan düz dokumaları üç sınıfa ayırabiliriz:

1- Geleneksel Sarız Dokumaları

2- Değişik illerden gelerek Sarı'a yerleşen kişilerin, geldikleri yerlerdeki dokuma bilgilerini Sarız'a getirerek, uzun yıllar Sarı'da dokudukları dokumalar.

3- Son yıllarda düz dokumalara artan talepten dolayı Ticari amaçla dokunan dokumalar.

Yöre halkının temel geçim kaynağı hayvanclıktır. Çoğunlukla koyun ve keçi yetiştirilir. Buna paralel olarak da dokumalarda yün malzeme fazlaca kullanılmıştır. Yünlerin iplik haline gelinceye kadar geçirdikleri işlemler yöre halkı tarafından yapılmıştır. Son yıllarda ise ticari amaçla dokunan dokumalarda malzeme hazır getirildiğinden ve yünlerin iplik haline gelinceye kadar uygulanan aşamaların zahmetli olmasından dolayı yörede ip yapımıyla uğraşanların sayısı azalmıştır. Son yıllarda ise; pamuk, orlon gibi malzemelerin kullanımı yaygınlaşmıştır. Koyunlar yılda iki kez kırkılır. Kırkımdan sonra; yün/ kıl tarağı ve yay ile lifler tel tel ayrılır. Taranarak ve Yay ile atılarak lifleri açılan yün, istenilen kalınlıkta eğrilip bükülerek iplik haline getirilir.

9 Gülderen Kılıç; Sarız ve Çevresinde Yaşayan Avşarların Örf ve Adetlerinin Tetkiki, Yayınlanmamış Lisans tezi (E.Ü. İlahiyat Fak.), Kayseri 1996, s.9.

10 Mehmet Arık; Sarız Tarihi, Yayınlanmamış Lisans Tezi (E.Ü. İlahiyat Fak.), Kayseri 1983, s.13 
Zahide KAYIŞOĞLU ŞAHIN

Eğrilen ipin bükülmesinin sebebi; ipin sağlamlığını arttırmaktır. Bu işlemi yapmada; Ĭğ, Kirman ve Çıkrık gibi aletler kullanılır. Kirman, ĭğdeki yuvarlak tahta yerine, çapraz olarak birbirine geçmiş iki tahtadan ve bir çengelli eksenden ibarettir. Bunda da iğ'de olduğu gibi iplik bükülür. Bükülen iplik çapraz tahtaların aralarına karşılıklı sarılır. Kirmanda yün, pamuk gibi kısa liflerin bükülmesinde kullanılır ${ }^{11}$. Ayrıca eğrilen ipler, gülcen (gülcan) da yumak haline getirilir. Günümüzde Sarız'da büküm aletler çok az kullanılmakta, kullanılmayan büküm aletleri ise yurt içi ve yurt dişına hediye edilmektedir.

Boyama: Sarız ilçesi ve köylerindeki dokumalarda; satın alınan ipler, doğal boyama yöntemleri ile boyanan ipler ya da piyasadan satın alınan toz boya ile boyanan ipler görülür. Bilinçli olarak dokumaya canlılık kazandırmak için bazı motifler orlon iplerle dokunmuştur. Yörede çile boyama yapılmakta ve çileye Kelep adı verilmektedir. Eskiden sadece yün iplikler boyanırken, artık pamuk ipliklerde boyanmaktadır. Boyama işlemi büyük bakır kazanlarda yapılmaktadır. Doğal boyama uygulanırken; tamamen yörede var olan bitkiler, soba isi, koyun tezeğinin külü gibi doğal kaynaklar kullanılmaktadır. Bazı bitkilerin boyar maddeleri yüne direkt geçerken, bazı bitkiler için ara maddeye ihtiyaç duyulur. Bu ara maddenin kullanımına mordanlama adı verilir. Mordanlama işlemine yörede Seğleme denilmektedir. Mordan maddesi olarak yörede genellikle şap kullanılır ve yörede şapa Seğ denilir. Canlı renkleri elde etmek için; Kayseri'den toz boya satın alınır. Genellikle uygulanan boyama yöntemi ise bitkiler ve toz boyaların bir arada uygulandı̆̆ boyama şeklidir. Sentetik boyaya yörede yamçı adı verilmektedir. Ayrıca eskiden Kemer köyünde boyacı veya küpçü adı verilen kişilerin, boyama işlerini yaptıkları köy halkı tarafından verilen bilgiler arasındadır. Dokumalarda kullanılan renklerin nasıl elde edildiği konusunda kısa bilgiler şu şekilde verilebilir:

Yeşil: Sütleğen otu kaynatılıp, içine satın alınan yeşil renkteki toz boya dökülerek elde edilir.

Gri: Yörede Boz renk olarak ifade edilir. Siyah ve Beyaz yünleri karıştırarak elde edilir. İpler boyandıktan sonra geride kalan boyalı sulardan da bu renk elde edilebilir.

Beyaz: Çoğunlukla Yünün kendi doğal rengi olarak kullanılır, boyama yapılmaz. Beyaz renk yörede anamalı şeklinde de söylenir.

Turuncu: İs kaynatılır, ip kaynatılmış isli suya bastırılır, tekrar kaynatılarak elde edilir. Turuncu renk yörede kınalı sarı olarak, ifade edilir.

Sarı: Soğan kabuğundan ve sütleğen otundan elde edilir. Sarı renk yörede çiğ sarı olarak ifade edilmektedir

Pekmez rengi: Yörede yetişen ve Çalpa bitkisi diye bilinen bitkiden elde edilir.

11 Hilmi Dülkadir: Mut ve Çevresinde Milli El Sanatlarımız ( Istar Dokuma), Dokuma Tekniği, Çeşitleri, Milli Gelenek, Görenek ve Sanatları Serisi: 1, Ankara, 1985,s. 17
Kahverengi ve Tonları: Meşe yaprağından, Ceviz kabuğundan elde edilir. Yörede kahverengi renk saz olarak ifade edilmektedir.

Kırmızı: Karamık bitkisinin kökünden elde edilmektedir.

Pembe: Şayak olarak söylenir. Hazır alınan toz boyalardan elde edilir

Siyah: Elma yaprağından, meşe palamudundan elde edilir.

Mor: Murt çalısından elde edilmektedir.

Elma yaprağı, Cevizin yeşil kabuğu ve yaprağı, karamık kökü, sütleğen otu, çalpa otu ile boyama yaparken renklerin akmaması için kezzap ve ekşi (sumak) atılmaktadır.

Son yıllarda Sarız'da ipler boyanmamakta, esnaf tarafından getirilen iplerle dokuma yapılmaktadır.

\section{Motif ve desen özellikleri:}

Yörede çuval, heybe, oklavalık, iğlik, ita, yastık vb. dokumalarda kilim ve cicim tekniğinde dokunmuş ve genellikle keklik izi (Çizim:6), solucan, göz, pıtrak, yarım pıtrak, pampal (gelincik), elibelinde, koçboynuzu, başak (Çizim: 13), vb. motifler kullanılmıştır. Sarız'da dokunan kilimlerde farklı özellikler göze çarpar. Erzurum, Kars, Yahyalı, Sivas, Van gibi yörelerden ilçeye göç olduğundan kilim dokumalarda karma etki hissedilir. Sarı' da uzun yıllar dokunan kilim dokumaları desen ve motif özelliklerine göre kendi arasında dört gruba ayrılabilir:

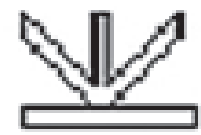

Çizim. 6 Keklik İzi

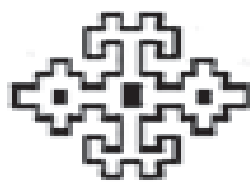

Çizim. 13 Başak
1- Seleser Kilim: Seleser kilim deseninde simetrik Elibelinde motifleri bulunmaktadır. (Fotoğraf: 1)

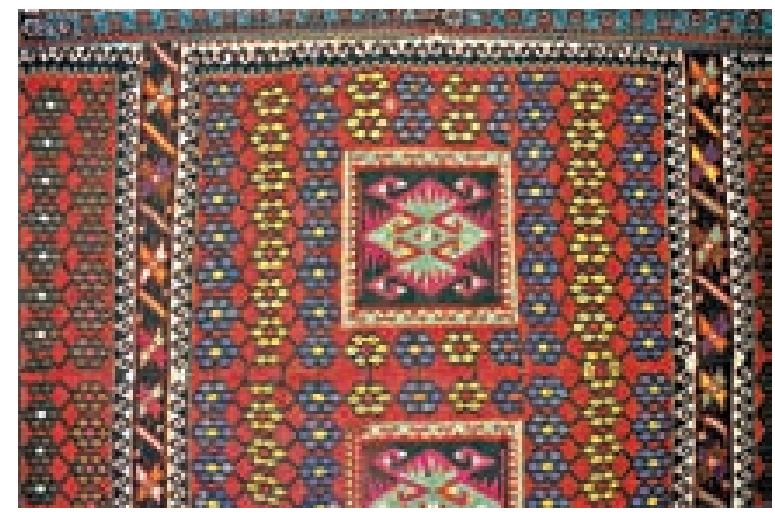

Foto. 1 Seleser desenli kilim 
2- Kuşlu Kilim: Desende kuş figürleri yer almaktadır (Çizim: 8). Bu desen Avar Kilimlerindeki desene benzemektedir. "Anadolu Figürlü kilimlerin güzel bir örneği olan Avar kiliminin orta zemininde büyük madalyon halinde, kenarlarında ve içinde belirgin bir şekilde uzun boyunlu kuş figürleri bulunan motifler vardır"12.

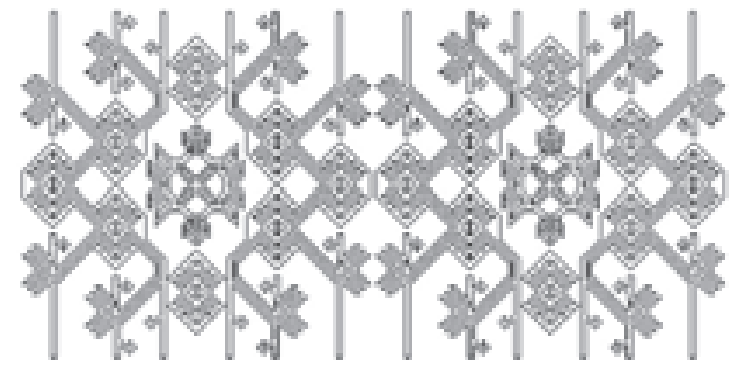

Çizim. 8 Kuşlu Kilim

3- Sandıklı Kilim: Desende değişik sayılarda sandık adı verilen geometrik şekiller (kare ya da kareye yakın dikdörtgen) yer alır. (Fotoğraf: 2)

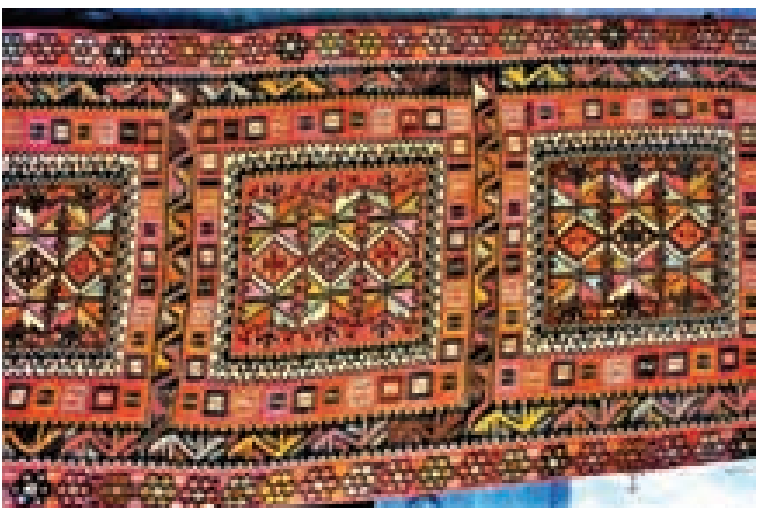

Foto. 2 Sandıklı kilim

4- Zincirli Kilim: İç zemindeki motiflerin birbirlerine eklenmiş gibi görünmelerinden dolayı bu isim verilmiştir. 2. sıradaki desenler 1. sıraya göre kaydırılmış eksende yer alır. (Fotoğraf: 3)

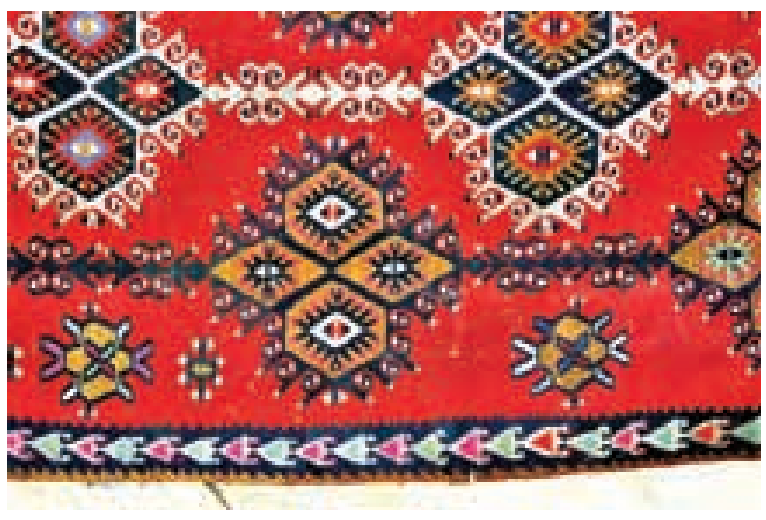

Foto. 3 Zincirli kilim

12 Fahrettin\&Naciye Kayıpmaz; "Avar Kilimleri”, AntikEDekor Antika, Dekorasyon ve Sanat Dergisi, Sayı:7, Temmuz-Ağustos-Eylül 1990, s. 115.
5- Dibekli Kilim: Desenin ortasında dibeğe benzer şekiller yer aldığından bu isim verilmiştir. Yörede ahşap dibekler yaygındır ve içinde genelde sarımsak ezilir. (Fotoğraf: 4)

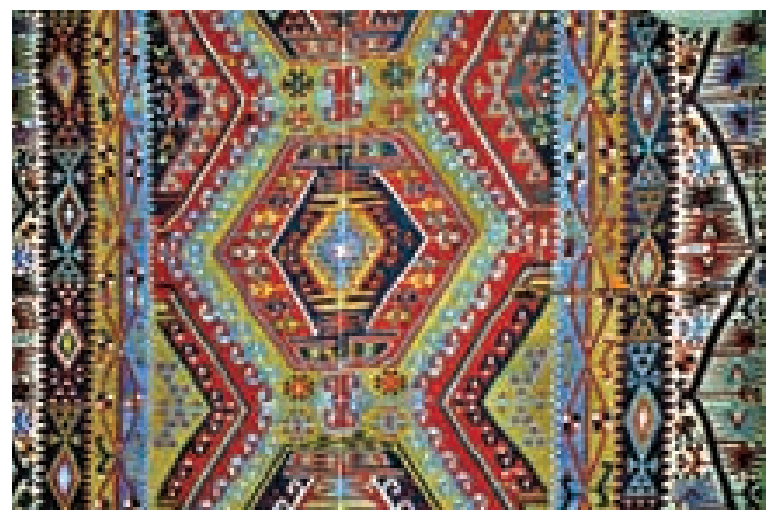

Foto. 4 Dibekli kilim

6- Soy Kilim: Renkli bantlar halinde dokunan dokumalara yörede tahta adı verilir. Motifsiz veya az motifli dokumalara soy kilim denir.

Tezgâh ve Avadanlıklar: Kayseri'nin diğer ilçe ve köylerinde çoğunlukla Germe Tezgâh tipi kullanılmasına rağmen, Sarız merkez ve köylerinde ahşap Sarma Tezgâh kullanılmaktadır. Böylece boyları uzun dokumalar dokunmuştur. Tezgâhlar genellikle evlerin oturma odalarındadır ve tavana sabitlenmiş haldedir. Yörede Sarma Tezgâh Istar veya İp ağacı şeklinde söylenmektedir. Dokuyucu ya daha önce dokunmuş dokumalardan kendine model alır veya da ezberindeki motiflerle dokumaya başlar. Dokuma yapılırken kullanılan avadanlıklar: bıçak ve kirkittir. Sarız köylerinde kirkite tarak denilmektedir. Yörede tezgah ve avadanlık sayıları çok hızlı şekilde azalmış, tezgah parçaları bahçe kenarlarına ağıl yapmakta kullanılmış veya yakılmıştır.

Dokuma Özellikleri ve Çeşit: Sarız merkez ve köylerinde düz dokumalardan özellikle kilim ve cicim dokuma tekniklerinde oldukça zengin dokumalar mevcuttur. Cicim dokuma tekniğine, tekniğin zorluğundan, zülüm gibi gelmesinden dolayı zülü denilmektedir. Sedef ve bordüre yelen/yeleni denilmektedir. Kompozisyonda boş yerlere gelişigüzel, boşluk doldurmak amacı ile yerleştirilen motiflere tapkır denilir. Sumak ve zili teknikleri, Kilim ve Cicim tekniklerine göre daha azdır. Sarma tezgâhta dokumaların boyları istenilen uzunlukta yapılmaya imkan sağladığından Sarız düz dokumalarının boyları oldukça uzundur. Yörede; Yer Kilimi, Duvar Kilimi, Sedir (Divan) veya Kanepe Yaygıları, Ahretlik Dokuma (Öbür Dünya Kilimi), Çuval, Yük Perdesi, Yük Kilimi, Heybe, Yastık, İta, Oklavalık, İğlik, Tuz Torbası/Çantası, Sütlük, Palaz/Palas gibi dokuma ürünlerine rastlanmıştır. 


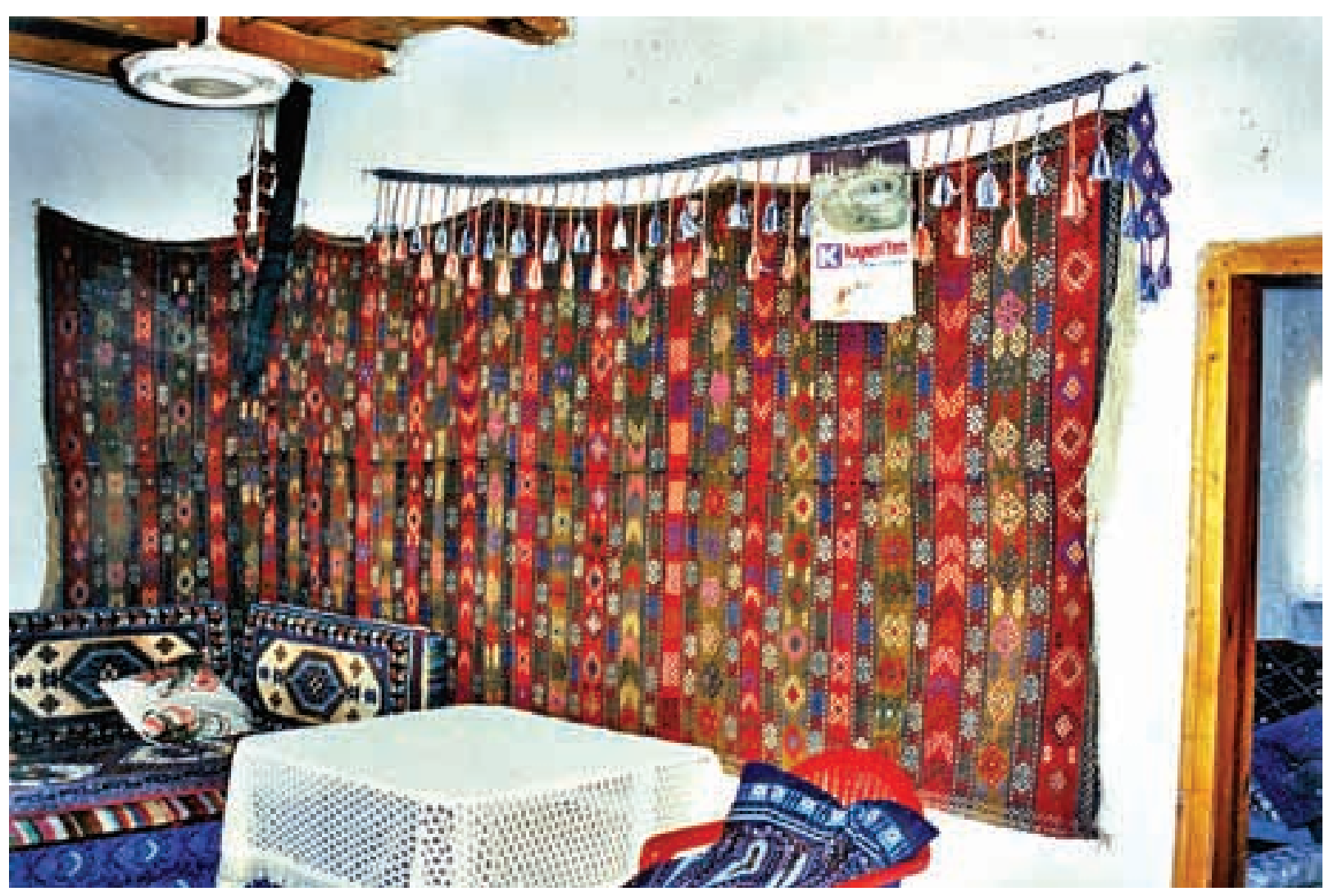

Foto. 6 Duvar yaygisı

Yer Kilimi: Yaygı olarak da söylenir. Yere sermek amacıyla kullanılır. 2 kanat (şak) şeklinde dokunur ve iğne ile sonra motifler simetri oluşturacak şekilde dikilir. Bazen Tek şak olarak da kullanılır. Takribi 200x400 cm. ebatlarındadır. Sarız merkezdeki evlerin çoğunda makine halısı bu dokumaların yerini almıştır.

Duvar Kilimi/Yaygısı: Sarma Tezgâhta istenilen ebatta dokuma yapabilme olanağı vardır. Sarız ilçesinin özellikle dokuma yapılan köylerinde, duvara kilim asma geleneği çok yaygındır. Yörede kilimler adeta duvara asmak için dokunmuştur. Artık dokuma sanatıyla uğraşmayan ailelerin evinde bile duvar kilimi asılıdır. Çoğunlukla odanın iki duvarını kaplayan ebatta duvar kilimlerinin yanında takribi aynı büyüklükteki odaların bazen üç duvarını da kaplayan kilimlerle de karşılaşılmıştır. Bazen bu kilimlerin üzerine aile bireylerinin fotoğrafları, ayna, av tüfeği vs. asılmıştır. "Bu kilimler hem duvarı süsler hem de duvardan gelebilecek soğuk ve nemi önler ${ }^{13}$. Duvar kilimleri belli bir süre kullanıldıktan, sonra yer kilimi olarak da kullanılmaktadır. (Fotoğraf:6)

Sedir (Divan) Veya Kanepe Yaygıları: Evlerin, oturma odalarına, ev halkının ve gelen misafirlerin oturmaları için konulan sedirlerin (divanların) veya

13 Bekir Deniz; Ayvacık (Çanakkale) Yöresi Düz Dokuma Yaygıları (KilimCicim-Zili), Atatürk Kültür Merkezi Başkanlığı Yayınları, Ankara, 1998, s. 15. kanepelerin üzerine serilen dokumalardır. Zaten günümüzde çoğu evde de sedir (divan) yerini kanepelere bırakmıştır. Sedir (divan) için yapılan dokumalar sonraları kanepeler üzerine serilir olmuştur. Dikdörtgen formunda olan bu dokumalar günümüzde sedir örtüsü veya kanepe örtüsü olarak eskisi kadar yaygın kullanılmamaktadır. Sarız ilçesinin özellikle Çağşak köyünde sedir (divan) veya kanepe örtülerinin güzel örneklerine rastlanmıştır.

Ahretlik Dokuma (Öbür Dünya Kilimi): "Anadolu'da kadınlar genç kızlığı sırasında veya evlendikten sonra kendisi ve kocası için sağlığında veya öldükten sonra hayrına camiye serilmek üzere halı ve düz dokuma yaygı dokur. Dokuma yapmasını bilmeyenler, ısmarlama yoluyla, başkasına dokuttururlar. Ölüm için dokunan örnekler taraflardan birisi ölünceye kadar saklanır. Özellikle yaşlı hanımlar bunları kefenlik bezleriyle birlikte sandığın bir köşesinde hazır halde bekletirler. Bu örnekler diğer dokumalar gibi alınıp satılmaz. Darda kalınsa bile elden çıkartılmaz. Öldükten sonra "kişinin bu dünyadan götürebileceği tek malın yaptığı iyilikler ve camiye bağışlayacağı bir kilim ve birkaç metrelik kefen olduğu" inanciyla dünyalık olarak saklanır. Erkek veya kadın öldüğünde, cenaze üzerine serilen düz dokuma yaygı, mezarlıktan dönüşte, ölen kişinin hayrına camiye serilir. Camiye bağışlanan bu halı veya düz dokuma yaygıya ölümlük 
(halı-kilim) denir. Bu amaçla dokunan halı ve düz dokuma yaygılar Anadolu'nun her yerinde değişik isimlerle tanınır. Sözgelimi Çanakkale yöresinde ölümlük kilim, Konya, Aksaray, Kayseri, Kırşehir çevresinde ahretlik kilim (öbür dünya kilimi), Manisa, Denizli, Aydın çevresinde sargı kilimi (tabuta sarılan kilim) adı verilir. Söz konusu bu dokumalar, bağışlandıktan sonra caminin malı sayılır. Hiç kimse tarafından alınıp satılamaz. Kullanma hakkı tamamen serildiği camiye aittir"14. Sarız ilçesine bağlı Büyüksöbeçimen Köyü Cami ve Karapınar Köyü Camileri Ahretlik dokumalar yönünden oldukça zengindir.

Yük perdesi: Sarız yöresi düz dokumaları denilince akla ilk önce duvar kilimleri sonrasında da yük perdeleri akla gelmelidir. Sarız merkez ve dokuma yapılan köylerde yüklük perdeleri çok yaygındır. Odanın bir kenarına iptidai şekilde yapılan, $55-60 \mathrm{~cm}$. yüksekliğinde seki üzerine mutlaka yörede çalma adı verilen sık motifli cicim ve kilim tekniğinde yük perdesi örtülmektedir. Üzerine de yatak, yorgan vs. malzemeler dizilmektedir. Yörede bu dokuma türünün genelde koyu kırmızı zeminli dokunduğu gözlemlenmiştir. Bir kanat olarak dokunup kullanılmaktadır. (Fotoğraf:5)

Yük Kilimi: Kilim halıdan daha hafif olduğundan kullanımı da pratiktir. Bu tür kilimler eşya taşımak için kullanıldığı gibi örtü amaçlıda kullanılır. Yatak, yorgan, kullanılmayan dokumalar, yastıklar vs. malzemeler, ahşaptan yapılmış, $55-60 \mathrm{~cm}$. yükseklikdeki seki üzerine üst üste dizilir ve üzerine kilim örtülür. Böylece hem eşyalar korunur hem de odanın bir kenarında toplanan eşyalar estetik bir görünüm kazanır. Genellikle İki kanat (şak) halinde kullanılır. Yaklaşı $120 \mathrm{~cm}$. genişliğinde ve $400 \mathrm{~cm}$. boyunda dokunmaktadir

Çuval: Sarız ilçesinin Kemer Köyü, çuval dokumaları yönünden oldukça zengindir. Çuvallar iki şekilde dokunmaktadır. Birinci şekil: çuvalın ön ve arkası ayrı ayrı dokunup sonradan birleştirilmektedir. İkinci şekil ise: yörede aykırı çuval adı verilen büyük ve tek parça halinde dokunur ve dokuma bittikten sonra ikiye katlanıp alt ve bir tarafın dikildiği çuvaldır. Aykırı çuvalda desen çuvalın önünde ve arkasında tek taraftadır. Yöre halkının aykırı çuvalı anlatırken, diğer çuval dokumasına göre daha az kıymet verdiği gözlenmiştir. Çuvalların desenleri genelde cicim tekniğinde, desensiz kısımlar ise kilim tekniğinde dokunmuştur. Yeşilkent (Yalak) Kasabasında içine çamaşır konulan çuvallara rastlanmıştır. Bu belde de çamaşır koymak amaçlı kullanılan bu dokumalara Karçın adı

14 Bekir Deniz; Ayvacık (Çanakkale) Yöresi Düz Dokuma Yaygıları (KilimCicim-Zili), Atatürk Kültür Merkezi Başkanlığı Yayınları, Ankara, 1998, s.14. verilmektedir. Çuvallar yün ve pamuk malzemeden dokunmuştur.

Yörede motif ve desen özelliklerine göre çuvallara isimler verilmiştir. Yılan Kovan Çuvalı, Boncuklu Çuval(Çizim:9), Belidar Çuval, Koçboynuzlu Çuval, Develi, Deve Boynu (Çizim:2), Deve Tabanlı Çuval (Çizim:1), Alaboncuk (Çizim:11), Başak(Çizim:13), Kurtağızlı pıtrak (Çizim: 14), Sığır Sidiği (Çizim: 12) Kız Kaçıran Çuvalı (Çizim:4) vb. Kız kaçıran çuvalı adını verdikleri desenden bir çuvalı çeyizi için dokumaya çalışan genç kız desenin zorluğundan dolayı dokumayı bırakıp kaçar ve desenin adı sonra Kız Kaçıran olarak kalır.

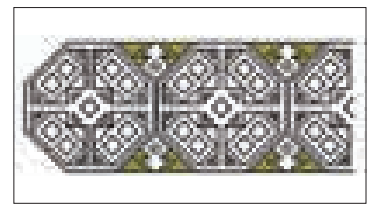

Çizim. 1 Deve Tabanı(Çuval Dokumalarında Görülür)

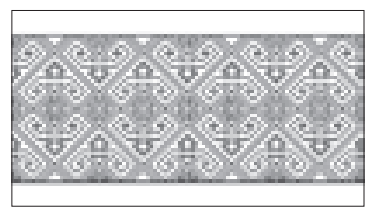

Çizim. 4 Kızkaçıran Çuval Deseni

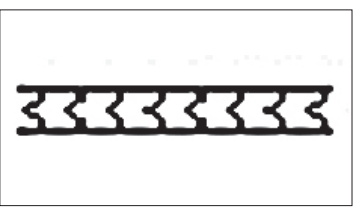

Çizim. 11 Ala Boncuk

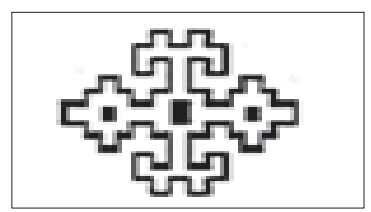

Çizim. 13 Başak

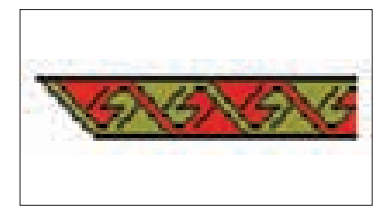

Çizim. 2 Deve Boynu

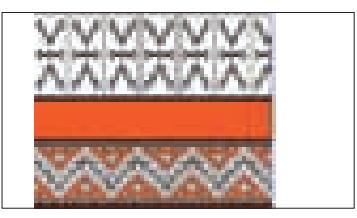

Çizim. 9 Boncuklu Çuval Deseni

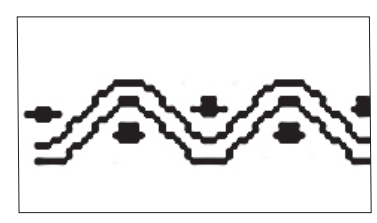

Çizim. 12 Sı ̆̆ır Sidiği

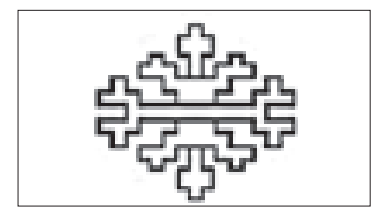

Çizim. 14 Kurt Ağızlı Pıtrak

Heybe: Yük taşımak için kullanılmaktadır. Genellikle yün ve keçi kılından dokunmuştur.

Palaz/Palas: Bu tür dokumalara; kapı önlerinde, saman yığınlarının üzerinde, ahşaptan yapılmış tuvaletlerin üzerine örtülmüş halde karşılaşılmıştır. Halkın önem vermediği dokumalardandır

Yastık: Yörede dokuma yastıkların sayıları oldukça azdır. Ortalama 60x120cm. ebatlarında dokunan yastıkların bazılarında her iki yüz desenli, bazılarında ise sadece ön yüz desenli olabilmektedir.

İta: Yörede, yemeklerde yufka ekmek yaygın yiyecek türüdür. Köydeki bayanlar ekmek tahtasında hamuru 
Zahide KAYIŞOĞLU ŞAHIN

oklava ile açarken unların yere dökülmemesi için ekmek tahtasının altına serdikleri örtüye yörede verilen isimdir. Özellikle çözgüler pamuk malzemeden dokunur. Pamuk malzemenin unları geçirmediğini ve o yüzden tercih ettiklerini belirtmişlerdir. Kilim tekniğindeki zemine küçük boyutlarda seyrek cicim tekniğinde motifler serpiştirilmiştir. Başak, Kıvrım (Çizim:5), Keklik izi (Çizim:6), Başak motifleri yaygın şekilde kullanılır. Kareye yakın ebatta dokunur.

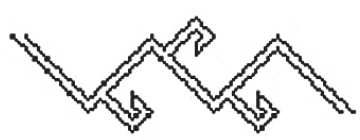

Çizim. 5 Kıvrım

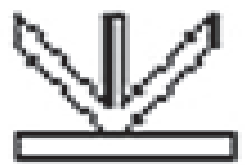

Çizim. 6 Keklik İzi
Oklavalık: Evlerin mutfaklarında kullanılmak üzere, dar ve uzun olarak dokunmuş içine oklava konulan dokumalardır. Duvara asılır.

İglik: Yöre halkının; yün eğirmek için kullandıkları; kirman, iğ gibi aletleri koydukları dar ve uzun dokumalarıdır. En olarak oklavalık ile aynı olmasına rağmen, boy olarak oklavalığın uzunluğunun yarısı kadar olmalıdır. Bu dokumalar da duvara asılır. (Fotoğraf:8)

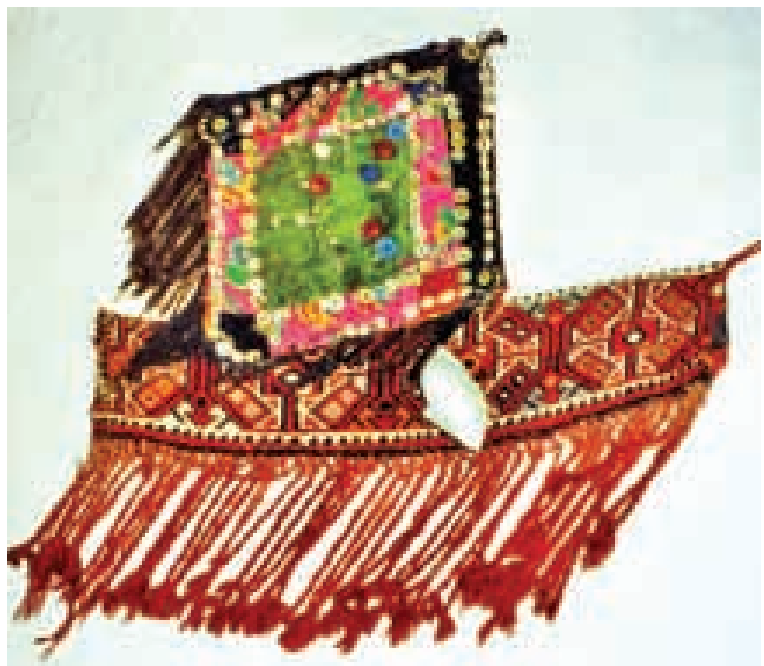

Foto. 8 İğlik

Tuz Torbası / Tuz Çantası: Çobanların, Özelliklede küçükbaş hayvanlarına tuz yedirmek için boyunlarına asarak yanlarında taşıdıkları içine tuz koydukları çantalardır. Ebat olarak yaklaşık 40x40cm.dir.

Sütlük: Tavla köyünde sütlük olarak ifade edilen dokuma ürünlerine rastlanmıştır. Sütlükler, çanta görünümünde olup, ortadan dikilmiş iki parça halindedir. Koyun derisinin lifleri temizlendikten sonra, kaynar suda kaynatılır. Sonra deri yere serilerek her tarafı tuzlanır. Böylece temizliği yapılır. Süt derinin içerisine konur. Deri, önceden dokunmuş olan çanta görünümündeki dokumanın içine yerleştirilir. Dokumanın bir tarafında uzun, bir tarafında kısa olan kulpları vardır. Bu kulplar sayesinde süt kolayca taşınılabilir. Dokuma içerisindeki deri, sütün yere dökülmesini engellemekte ve sütün korunmasını sağlamaktadır. Kilim zemin üzerine motifler cicim tekniğinde dokunmuştur. Sütlük adı verilen bu dokumaların yaklaşık ebatları: En: $45 \mathrm{~cm}$. X Boy: $60 \mathrm{~cm}$. dir. (Fotoğraf:7)

Yukarıda adı geçen dokuma türleri günümüzde neredeyse dokunmamakta, yöre halkı önceden dokudukları dokumalarıda özellikle Gaziantep'den gelen esnafa makine halısı karşılığı vermektedir.

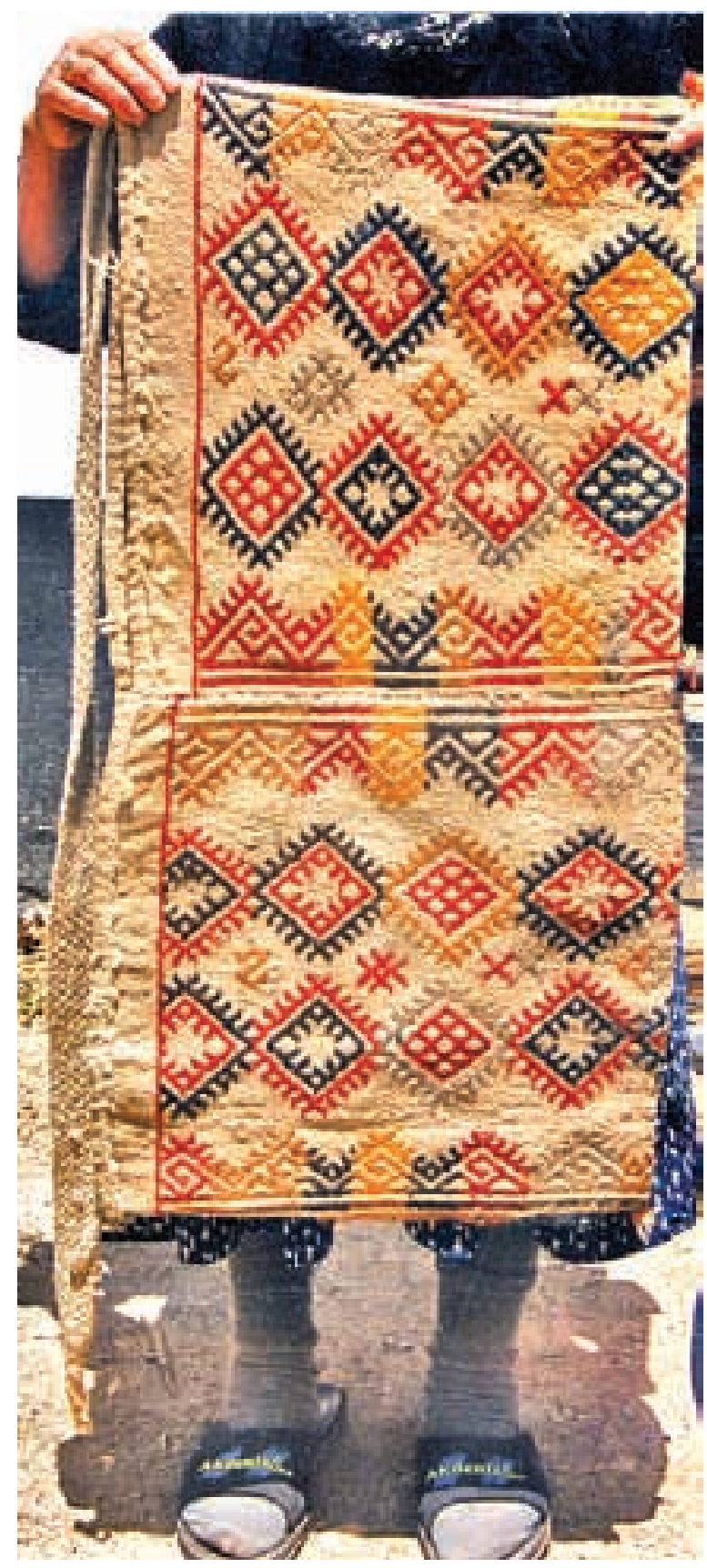

Foto. 7 Sütlük 


\section{Değerlendirme ve Sonuç}

Yörede uzun yıllar önce dokunmuş dokumaların ebatları çok büyüktür. Günümüzde genellikle ticari amaca yönelik dokunan dokumalarda büyük ebatlı dokumalar dokunmamaktadır. "Geleneksel düz dokumalarımızda malzeme, saf yünden el eğirmesi iplerdir. Son yıllarda satın alınan yün, pamuk, orlon gibi ipliklerin kullanımı yörede yaygınlaşmıştır. Eskiden yapılan dokumalarda doğal boyama yöntemleri yaygın olarak kullanılmakta iken, günümüzde boyama neredeyse yapılmamakta, ipler boyanmış halde satın alınmaktadır. Eski dokumalarda kullanılan desenler anneden kıza miras şeklinde bir sonraki nesle aktarılır, dokuma yapabilecek yaşa gelmiş bir kız çocuğu, annesinin yaptığı dokumayı görerek deseni ezberine alırdı. Günümüzde ağırlıklı olarak ticari amaca yönelik dokumalar yapıldığından, piyasanın isteğine göre hazırlanmış kimlikleri olmayan desenler yöreye, esnaf eli ile getirilmektedir. Son yıllarda geleneksel dokumalara artan talebin paralelliğinde, dokumalarıyla ünlenmiş, yörelere giderek, para veya makine halısı karşılığında, yörelerin renk, motif, kompozisyon, ebat, malzeme vb. yönünden karakteristik dokumaları toplanmış veya toplanmaktadır. Sarız yöresi halkı; kendi elleriyle ürettikleri dokumaların, sanat eseri olduğundan habersiz özellikle Gaziantep'den gelen makine halısı satıcılarına, el dokumalarını vererek makine halısı almaktadır. 1997 yılında, kaymakamlık öncülügüunde Sosyal yardımlaşma ve Dayanışma Vakfınca ilçede 100 adet kilim tezgahı yaptırılarak kilim dokuma atölyesi kurulmuştur fakat birkaç yıl içinde kapatılmıştır ${ }^{15}$.

Sarız ilçesinde ekonomik nedenlerden dolayı yurt dışına gidenlerin sayısında artış olmuştur. Yörede dokunmuş dokuma örnekleri, avadanlıklar, büküm aletleri vb. böylece yurt dışına götürülmüş ya da götürülmeye devam etmektedir. Sarız ve çevresinde çok moda olan bir uygulama ise: Düz dokumalardaki motiflerin orlon iplerle şişte örülmesidir. Bu uygulama o kadar popüler hale gelmiştir ki tezgâhta dokuma yerine elde örülerek yurt dışına gidenler aracılığı ile pazarlanmaktadır. Sarız yöresindeki halk ile görüşmelerde zaman zaman "dokumalarımızı sattık, son yıllarda da dokumuyoruz, şimdiye kadar neden gelip araştırmadınız" gibi sorularla karşılaşılmıştır. Köy araştırmalarımız sıra- sında tezgâhların parçalanarak bahçe kenarlarına çit yapımında kullanıldığı gözlemlenmiştir.

Yörede geleneksel anlamda dokunmuş dokumalarda çiti örülmediği gözlenmektedir. Saçaklar saç örgüsü şeklinde yapılırken son yıllarda makreme örgü teknikleri saçaklarda görülmeye başlanmıştır.

\section{Kaynaklar}

Arık, Mehmet; Sarız Tarihi, Yayınlanmamış Lisans Tezi (E.Ü. İlahiyat Fak.), Kayseri 1983.

Cumhuriyetimizin 75. yılında Kayseri; Kayseri Valiliği 1998.

Deniz, Bekir; Ayvacık (Çanakkale) Yöresi Düz Dokuma Yaygıları (Kilim-Cicim-Zili), Atatürk Kültür Merkezi Başkanlığı Yayınları, Ankara, 1998.

Dulkadir, Hilmi; Mut ve Çevresinde Milli El Sanatlarımız; Istar Dokuma), Dokuma Tekniği, Çeşitleri, Milli Gelenek, Görenek ve Sanatları Serisi: 1, Ankara, 1985.

Kayseri'de El Sanatlarl; Türkiye Cumhuriyeti Kayseri Turizm, Kültür, Sanat ve Araştırma Vakfı Yayınları no: 3.

Kayıpmaz, FahrettinaNaciye; "Avar Kilimleri”, Antik\&Dekor Antika, Dekorasyon ve Sanat Dergisi, Sayı:7, TemmuzAğustos-Eylül 1990

Kılıç, Gülderen; Sarı Ve Çevresinde Yaşayan Avşarların Örf Ve Adetlerinin Tetkiki, Yayınlanmamış Lisans tezi (E.Ü. İlahiyat Fak.), Kayseri 1996.

Subaşı, Muhsin İlyas; Dünden Bugüne Kayseri, Geçit Yayınevi, Kayseri 1998, 4. bask1.

15 Cumhuriyetimizin 75. yılında Kayseri; Kayseri Valiliği 1998, s. 248-252. 